Parle, J. N. (1957). J. gen. Microbiol. 17, 363-367

\title{
Yeasts Isolated from the Mammalian Alimentary Tract
}

\author{
By J. N. PARLE* \\ Microbiology Department, University of Otago, Dunedin, New Zealand
}

SUMMARY: A survey of the yeasts found in the alimentary canal of 169 animals has been carried out. Representatives of 17 species and 6 genera were isolated but of these only 4 species, Torulopsis pintolopesii, Saccharomycopsis guttulata, Candida albicans, and T. glabrata were considered to be true intestinal types. C. parapsilosis and $C$. kruse $i$ were classed as intermediates and the remainder as transients. The validity of the species $T$. pintolopesii is considered doubtful.

Although the yeast flora of the human alimentary tract has been studied to some extent little is known of the yeasts which occur in other animals. A few early investigations such as those of Catanei (1925) on monkeys and Talice (1932) on hedgehogs established the presence of members of the genus Candida in the intestines of healthy animals. De Mello (1940) reported the presence of Candida and Geotrichoides spp. in the intestines of normal laboratory animals. Coutelon \& Cochet (1942) also investigated laboratory animals but reported only those species of medical interest from the yeasts isolated. In a survey of fungi isolated from suspected mycotic infections of domestic animals Ainsworth \& Austwick (1955) noted the importance of the yeast component in the mycoflora of the alimentary canal and respiratory organs. The present survey covers a somewhat wider range of animals than those previously noted.

\section{METHODS}

Samples were taken from 169 animals : 14 cows, 30 rabbits, 15 sheep, 10 guinea pigs, 5 opossums, 10 monkeys, 15 cats, 10 dogs, 10 hedgehogs, 15 mice, 20 pigs and 15 rats.

\section{Sampling and cultivation techniques}

Wherever possible the animals were sacrificed and samples were taken from the stomach, small intestine and large intestine. Appropriate sections of the alimentary tract were removed aseptically and their contents expressed into sterile Petri plates. Material from each section was inoculated on to the surface of Sabouraud agar $(\mathrm{pH} \mathrm{4.0)}$ and also into glucose yeast-extract broth ( $\mathrm{pH} 4 \cdot 0$ ). In cases where the animal could not be killed samples of fresh faeces were cultured by inoculating material from the centre of the specimen on to Sabouraud agar and also into glucose yeast-extract broth.

Sabouraud agar proved unsatisfactory for the isolation and growth of Torulopsis pintolopesii van Uden, a fastidious yeast found in rats and mice, and a medium containing liver extract was used to isolate and maintain this species. Glucose yeast-extract broth at $\mathrm{pH} 4 \cdot 0$ was completely satisfactory for the

* Present address : Rukuhia Soil Research Station, Hamilton, New Zealand. 
primary isolation of all species of yeasts found during this survey, the low $\mathrm{pH}$ value and restricted nitrogen source diminishing bacterial growth to a considerable extent. All cultures were incubated at $37^{\circ}$ to exclude species unable to grow at the body temperature of the animals examined, and were kept for a week before being discarded as negative.

The methods proposed by Lodder \& Kreger-van Rij (1952) were used throughout this survey for the identification and classification of the yeasts isolated. Methods for the identification of Saccharomycopsis guttulata were based on morphology and ecology, the organisms are large and vacuolated and have a distinctive growth form. Ascospores, which were produced on Gorodkowa agar, are oval and up to three are formed per ascus. Ecologically the species is restricted almost entirely to the rabbit. An investigation of some of the physiological properties of $S$. guttulata was carried out (Parle, 1956).

\section{RESULTS}

Yeasts were isolated from 107 of the animals sampled and members of 6 genera and 17 species were obtained. In certain animals dominant yeast species appeared. This was particularly marked in the case of two unusual types: Saccharomycopsis guttulata which occurred in all the rabbits and Torulopsis pintolopesii which was found in all the guinea pigs, $73 \%$ of the mice and $66 \%$ of the rats examined. Candida albicans was the dominant species found in hedgehogs, sheep and opossums and was the most widely distributed of the species isolated. The remaining yeasts appeared to be rather sporadic in their distribution and many species were isolated only once or twice throughout the survey.

\section{DISCUSSION}

Yeasts isolated from the alimentary canal may be divided into two classes, those belonging to the true intestinal flora and those which are merely transitory in nature being ingested with the food. The physiology and distribution of the yeasts isolated during the survey were the criteria used to distinguish between these two groups. Only yeasts which require environmental conditions, including special growth factors, similar to those found in the intestine, or yeasts which occurred commonly in the intestine but have rarely if ever been reported outside it, were considered to be true intestinal types. Yeast species which are commonly found in situations other than the alimentary canal were considered to be transients. A division based on these criteria must necessarily have somewhat indefinite boundaries but in the present state of knowledge no other system of classification appears to be any more satisfactory. Of the 17 species isolated from the animals examined, only four, Saccharomycopsis guttulata, Torulopsis pintolopesii, T. glabrata and Candida albicans were considered to belong to the true intestinal flora. C. parapsilosis and C. krusei may also belong to this group but their position is rather doubtful. 
Table 1. Animals sampled and species of yeasts isolated

$\begin{array}{lllllllllllllllllll}\text { Number sampled. } & . & . & . & . & . & .14 & 10 & 5 & 30 & 15 & 10 & 15 & 10 & 10 & 15 & 20 & 15 & 169\end{array}$

$\begin{array}{llllllllllllllllllll}\text { Number positive. } & . & . & . & . & . & . & 6 & 10 & 3 & 30 & 15 & 8 & - & 7 & 10 & 11 & 10 & 10 & 120\end{array}$

$\begin{array}{llllllllllllllllll}\text { Candida albicans (Robin). Berkhout. Lodder \& } & \cdot & \cdot & \mathbf{3} & \cdot & \mathbf{8} & \mathbf{3} & \cdot & \mathbf{2} & \mathbf{9} & \cdot & 1 & \cdot & & & & \end{array}$

Kreger-van Rij (1952), p. 466, figs. 170-2

C. krusei (Castellani). Berkhout. Lodder \&

Kreger-van Rij (1952), p. 492, figs. 178-9

C. mycoderma (Reess) Nov. comb. Lodder \&

Kreger-van Rij (1952), p. 477, figs. 173-4

C. parapsilosis (Ashf.) Lang. et Talice. Lodder \& . $\quad$ • $\quad 5 \quad 2$

Kreger-van Rij (1952), p. 553, figs. 209-210.

C. tropicalis (Caste.) Berkhout. Lodder \& Kreger-

van Rij (1952), p. 502, figs. 182-3

C. utilis (Henneberg) nov.comb. Lodder \& Kreger-

van Rij (1952), p. 546, figs. 205-6

Torulopsis famata (Harrison) nov.comb. Lodder \&

Kreger-van Rij (1952), p. 417, fig. 147

$T$. glabrata (Anderson) Lodder et De Vries. Lodder

\& Kreger-van Rij (1952), p. 407, fig. 142

T. pintolopesii (van Uden), van Uden (1952)

Trichosporum capitatum (Diddens \& Lodder).

Lodder \& Kreger-van Rij (1952), p. 634,

figs. 255-6

T. cutaneum (de Beurm., Gougerot \& Vaucher)

Ota. Lodder \& Kreger-van Rij (1952), p. 169,

figs. 246-7

T. pullulans (Lindner) Diddens et Lodder. Lodder 3

\& Kreger-van Rij (1952), p. 615, figs. 244-5

Rhodotorula minuta (Saito). Harrison. Lodder \& .

Kreger-van Rij (1952), p. 663, fig. 267.

R. mucilaginosa (Jorgensen) Harrison. Lodder \& .

Kreger-van Rij (1952), p. 655, fig. 264.

Hansenula anomala (Hansen) H. et P. Sydow.

Lodder \& Kreger-van Rij (1952), p. 251,

figs. 73-5

Saccharomyces cerevisiae Hansen. Lodder \&

Kreger-van Rij (1952), p. 123, figs. 22-3

Saccharomycopsis guttulata (Robin) Schiönning.

Lodder \& Kreger-van Rij (1952), p. 299,

figs. 100-101

Saccharomycopsis guttulata. This yeast is extremely specialized in both its habitat and growth requirements. It is found in the intestines of rabbits and occasionally in guinea pigs (Lodder \& Kreger-van Rij, 1952). Microscopic examination of the intestinal contents showed a $100 \%$ incidence in the rabbits sampled, although it was not found in any of the other animals studied. Considerable difficulty was experienced in attempts to isolate $S$. guttulata and identification depended on its microscopic appearance.

Torulopsis glabrata. Only three strains of this organism were isolated, but since it has rarely been found except in association with the animal body it was considered to belong to the true intestinal flora. 
Torulopsis pintolopesii. This yeast was first reported by van Uden (1952), who isolated it from the livers of sick mice. Rats and mice of wild and of laboratory varieties, and guinea pigs, seem to harbour this yeast. Samples of food and litter from cages containing animals carrying $T$. pintolopesii were examined but the organism was not isolated except from faeces or intestinal contents. The limited distribution of this organism may be due to two factors, the restricted temperature range $\left(18^{\circ}-40^{\circ}\right)$ over which growth will occur, and its requirement for some as yet unidentified growth factor. The validity of the species $T$. pintolopesii seems somewhat doubtful since except for its unusual growth factor and temperature requirements the organism is indistinguishable from $T$. glabrata. In a group as phylogenetically heterogeneous as the Torulopsidae the requirement for a specific growth factor does not seem reason enough to establish a new species especially as some strains of $\boldsymbol{T}$. glabrata are difficult to grow on common laboratory media. Further investigation of this problem may indicate that $T$. pintolopesii should be classed as a variant of $T$. glabrata rather than as a separate species.

Candida albicans. This yeast occurs widely in animals and has been reported in humans by a number of workers (Benham \& Hopkins, 1933; Marples \& di Menna, 1952; Bezjak, 1954), in rats, rabbits, hens and pigeons by Coutelon \& Cochet (1942), domestic birds, dogs and cattle by Ainsworth \& Austwick (1955), and the European hedgehog by Talice (1932). Because of its wide distribution in the intestines of animals there must be an almost constant inoculation of the soil with this yeast. However, although several workers have investigated soils $C$. albicans has been isolated with certainty on only three occasions from this source, by di Menna (1955). Such a distribution is of some interest ecologically since $C$. albicans unlike Saccharomycopsis guttulata and Torulopsis pintolopesii is not fastidious in its requirements. It is possible that the antibiotics which are produced by a number of soil fungi and which are known to be active against $\boldsymbol{C}$. albicans are responsible for its rather sporadic occurrence in soil.

Candida parapsilosis and C. krusei. These have been isolated from the animal body both as saprophytes and possible parasites on numerous occasions but they also occur commonly in soil and on vegetation. Because of the methods used here to divide the yeasts into true or transitory flora these species occupy an intermediate position in this classification and must continue to do so until more is known of the role of yeasts in the alimentary canal.

All members of the remaining eleven species isolated from various animals were classed as transients and probably entered with the food.

A strain of Torulopsis pintolopesii has been deposited with the Centraalbureau voor Schimmelcultures (Yeast Division), Delft, Netherlands.

My thanks are due to Dr M. E. di Menna of the University of Otago Medical School for advice and encouragement during the course of this work. 


\section{REFERENCES}

Ainsworth, G. C. \& Austwick, P. K. C. (1955). A survey of animal mycoses in Britain. Trans. Brit. mycol. Soc. 38, 376.

Benham, R. W. \& Hopkins, A. M. (1933). Yeast-like fungi found on skin and in the intestines of normal subjects. Arch. Derm. Syph., N.Y. 28, 532.

Bezjak, V. (1954). Incidence of yeast-like fungi in the oral cavity. Acta Medica iugosl, vIII, 2, 200.

Catanei, A. (1925). Presence d'un Monilia sur la langue de singes d'Algerie. C.R. Soc. Biol., Paris, 93, 92.

Coutelon, F. \& Cochet, G. (1942). Les rongeurs domestiques, reservoirs de virus en mycopathologie humaine et veterinaire. Ann. Parasit. hum. comp. 19, 85.

Lodder, J. \& Kreger-van RiJ, N. J. W. (1952). The Yeasts. Amsterdam: North Holland Publishing Company.

Marples, M. J. \& DI Menna, M. E. (1952). Incidence of Candida albicans in Dunedin New Zealand. J. Path. Bact. 64, 497.

Mello, I. F. DE (1940). A report on the characters and identification of the yeasts living in commensalism in the intestine of some laboratory animals. Proc. Indian Acad. Sci. (Sect. B), 12, 17.

Menna, M. E. DI (1955). A search for pathogenic species of yeasts in New Zealand soils. J. gen. Microbiol. 12, 54.

Parle, J. N. (1956). The growth of Saccharomycopsis guttulata. Leeurenhoek ned. Tijdschr. 22, 237.

Talice, R. V. (1932). Parasitisme des Herissons par les Mycotorulees. Ann. Parasit. hum. comp. 10, 81.

Uden, N. vaN (1952). Zur Kenntnis von Torulopsis pintolopesii sp.nov. mit Beobachtungen über die parasitäre Phase von Acladium castellanii Pinoy. Arch. Microbiol. 17, 199.

(Received 4 March 1957) 